\title{
Toward a theory of entry in moral markets: The role of social movements and organizational identity
}

Strategic Organization 2020, Vol. I8(I) 50-74 (c) The Author(s) 2019

(c) (1) (8)

Article reuse guidelines: sagepub.com/journals-permissions DOI: $10.1177 / 1476127019827474$ journals.sagepub.com/home/soq

(B) SAGE

\author{
Panayiotis (Panikos) Georgallis \\ University of Amsterdam, The Netherlands
}

\section{Brandon Lee}

The University of Melbourne, Australia

\begin{abstract}
A growing body of research on moral markets-sectors whose raison d'être is to create social value by offering market solutions to social and environmental issues - has offered critical insights into the emergence and growth of these sectors. Less is known, however, about why some firms enter moral markets while others do not. Drawing from research on market entry, organizational identity, and social movements, we develop a theory that highlights the potential of organizational identity to explain variation in entry into moral markets. We then expand our framework by theorizing about contingencies that alter the shape of the relationship between organizational identity and market entry: the flexibility of the organizations' identity, the type, and orientation of the social movement supporting the moral market, and the mode of market entry (de novo vs de alio). Finally, we discuss the contributions of our framework and opportunities for its extension.
\end{abstract}

\section{Keywords}

market entry, markets, moral markets, organizational fields, organizational identity, social movements, sustainability

\section{Introduction}

The economic landscape is increasingly characterized by the development of moral markets - sectors that are not only concerned with wealth creation but whose raison d'être is to create social value by addressing the negative externalities associated with conventional 
practices, legacy technologies, and extant institutions (see Conger et al., 2018; Corbett and Montgomery, 2017; McInerney, 2014). Because of their unique potential for social change, moral markets are distinct from conventional markets in two ways. First, while arguably all markets can offer some social benefits - and, similarly, any market can have problematic elements (Fourcade and Healy, 2007)_-moral markets exist to create social value and thus their products, services, and/or respective means of production are considered to be normatively superior to alternatives. Second, moral markets are typically supported by organized actors (usually social movements) motivated by moral or normative considerations rather than only by the pursuit of economic interest. Indeed, sectors responsible for important social and economic change such as renewable energy, socially responsible investment, green buildings, organic food, sustainable forestry, grass-fed meat, fair trade goods, and recycling can all attribute some degree of their existence, growth, or survival to mobilization by social movement activists (Arjaliès, 2010; Durand and Georgallis, 2018; Jaffee and Howard, 2010; Lee et al., 2018; Lounsbury et al., 2003; Sine and Lee, 2009; Weber et al., 2008; York et al., 2018; Zietsma and Lawrence, 2010).

Despite the development of moral markets, research in strategy and organization theory has little to say about which firms decide to enter moral markets or how social movements in particular influence firm-level market entry decisions. Much of the strategy literature has explained market entry based on idiosyncratic firm resources and capabilities (Helfat and Lieberman, 2002; Mitchell, 1989; Tripsas and Gavetti, 2000), while paying limited attention to the social context in which entry decisions occur (Aldrich and Fiol, 1994; Pacheco and Dean, 2015; Tolbert et al., 2011). This is an important oversight because firms face pressure or inducements to enter moral markets not necessarily because of the resources they possess but because of "who they are" as an organization: their organizational identity (Albert and Whetten, 1985; Navis and Glynn, 2010; Tripsas, 2009). At the same time, while organization theorists have empirically demonstrated that social movements influence market dynamics (e.g. Hiatt et al., 2009; Pacheco et al., 2014; Sine and Lee, 2009), their findings provide little insight into which firms enter moral markets and which do not. These gaps in the literature suggest potential gains from integration across these distinct but related streams of literature.

In this article, we focus on organizational identity and develop theory about its role in the relationship between social movements and entry in moral markets. Our purpose is twofold. First, by drawing attention to the role of organizational identity for entry in moral markets, we offer a partial correction to the resource-centric explanations of market entry and underscore the criticality of organizational identity for new market opportunities (Navis and Glynn, 2010; Tripsas, 2009). Second, we provide a theoretical perspective that combines organization theorists' focus on the potential of social movements to shape markets with strategy scholars' emphasis on firm-level variation in market entry decisions.

We begin by discussing the role of organizational identity in two preconditions for market entry to occur: the identification and the evaluation of opportunities (McMullen and Shepherd, 2006). Then, after briefly summarizing the literature on moral markets-focusing on the mechanisms by which social movements induce market entry-we develop theory that addresses the question of why some firms are influenced by the efforts of social movements to shape a market while others are not. We argue that organizational identity has an asymmetric effect on entry in moral markets. The presence of a social movement increases the likelihood that a firm will identify the market opportunity when the firm's identity is congruent with the nature of the market, but also when its identity is oppositional to what is expected from market participants. Furthermore, market entry is more likely for firms with a congruent identity than for firms with an oppositional identity, and more likely for firms with an oppositional identity than for firms whose identity is unrelated to the 
market. As a result, social movements can drive diversity in moral markets (Durand and Georgallis, 2018), bringing in firms with both congruent and oppositional identities. The balance between the two groups is further complicated by additional factors that affect this relationship: the flexibility of the organization's identity, the nature and framing-tactic orientation of the social movement supporting the moral market, and the mode of entry of the organization - de novo versus de alio entry (Khessina and Carroll, 2008).

Our first contribution to the literature lies in extending theory on moral markets to address a critical and largely unconsidered question: why do some firms enter these markets while others do not? Addressing the limited theoretical advancements in the field of market entry (Zachary et al., 2015), the consideration of social movements together with organizational identity speaks to the question of how market entry decisions depend on the confluence of organizational and environmental factors, and to broader questions of how firms are differentially molded by social environments. Second, directing attention to social movements and identity in market entry decisions contributes to strategy research by expanding the determinants of market entry beyond resources and capabilities. Finally, we identify scope conditions for our theory and offer a theoretically derived agenda for future research that can guide scholars as they attempt to further advance understanding of moral markets.

\section{Background and theory development}

Shane (2012) alluded to our limited knowledge of how the environment shapes the identification and exploitation of opportunities, and the role of firm characteristics in the process. Similarly, analysts of social movements and organizations have called for theorizing how the impact of social movements differs across firms (Bartley and Child, 2011; Durand and Georgallis, 2018). These observations give rise to an understudied question: why do some firms enter moral markets while others do not? We address this question by theorizing how the participation of social movements changes the influence of organizational identity on market entry. Before that, we first specify basic definitions and assumptions of our framework and state baseline expectations about market entry and organizational identity.

\section{Market entry}

Following Helfat and Lieberman (2002), we define market entry as the initial production of a product or provision of service by a firm for a particular market. Our theory does not apply exclusively to novel products or services. By "initial" we mean that the market for the product or service is new to the focal organization. Moreover, we see the moral market not as an objective reality but as socially constructed. A market becomes "real" as more and more producers come to occupy a potential market space by offering similar products or services, establishing structured exchange with buyers, and eventually getting "counted," or cognitively defined and collectively recognized as a separate market or market niche (Kennedy, 2008; Lee et al., 2018). The market may be nascent or more developed; our arguments are applicable to different stages of the market. Nevertheless, we elaborate on this point in the discussion section.

We assume that the presence of a market opportunity and its identification are preconditions for market entry to occur (Denrell et al., 2003; McMullen and Shepherd, 2006). The word presence suggests not an objective and universally accepted truth but the mere perception of a decisionmaker that there is an opportunity for market entry. Opportunity identification denotes attention to the opportunity and is a necessary condition for market entry, but it is not a sufficient one (Penrose, 2009). Evaluation of an opportunity together with an actor's characteristics follow identification 


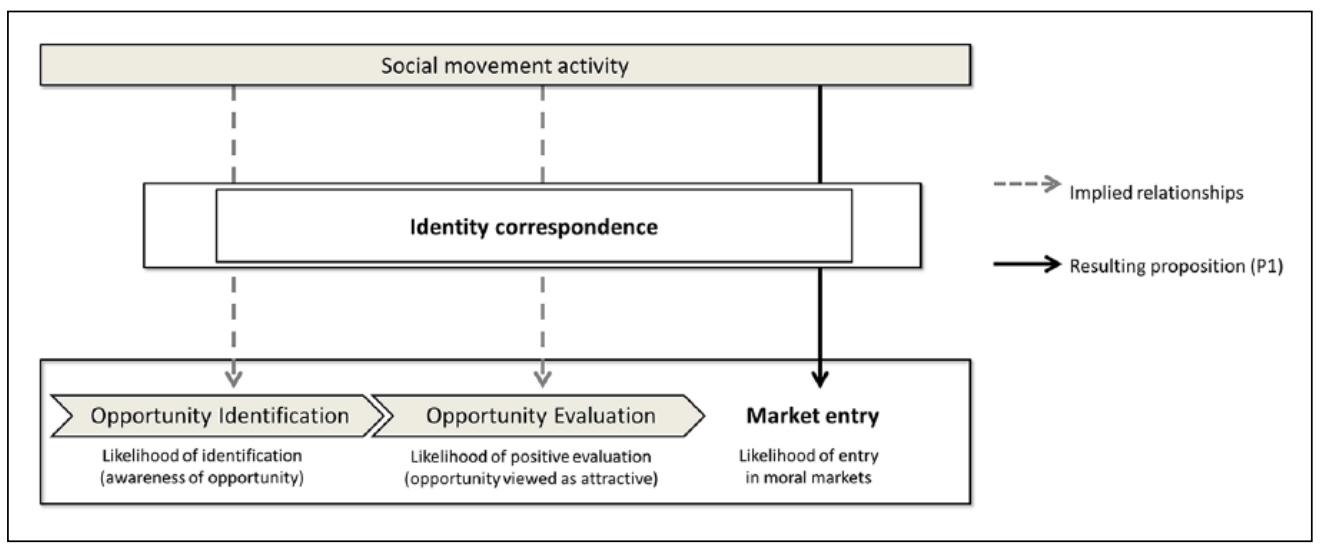

Figure I. Identity correspondence and entry in moral markets.

Identity correspondence filters the identification and evaluation of moral market opportunities promoted by the social movement (dashed gray line). As a result, identity correspondence affects the likelihood of entry in moral markets (black solid line).

and determine whether market entry will be pursued by the focal actor or not (McMullen and Shepherd, 2006; Penrose, 2009). The two stages are depicted in Figure 1.

While we separate the entry decision into the two stages of opportunity identification and evaluation (McMullen and Shepherd, 2006), we do not assume that all entry decisions are made precisely in this manner. Often the two stages overlap or happen in tandem, but separating identification from evaluation provides two important benefits. First, the distinction enables us to break down the entry decision into meaningful components that are likely to be encountered in real-life situations. Actors do not see an opportunity and decide on the spot. Instead, there is often an additional stepbe it formal or informal, elaborate or effortless - where the opportunity is evaluated. Second, this distinction enables us to better unpack how social movements and organizational identity influence this important decision. Overall, this approach allows us to be abstract enough to provide a parsimonious but still generalizable theory.

\section{Organizational identity and entry in conventional markets}

A rich body of work on market entry relies on firm-specific explanations centered on idiosyncratic firm resources or capabilities (e.g. Barney, 1991; Helfat and Lieberman, 2002; Moeen, 2017). Resources and capabilities are important for understanding market entry because they guide the search for new opportunities and shape the likelihood of market entry success (see Helfat and Lieberman, 2002, for a review). Organizational identity has received less attention in this literature, despite its importance for how firms identify and evaluate market opportunities (Tripsas, 2009).

Organizational identity is conceptualized here as the collective understanding, shared among organizational members and key audiences, of the defining elements that encompass what the organization "is" (Albert and Whetten, 1985; Nag et al., 2007; Navis and Glynn, 2010; Tripsas, 2009). In line with prior research, we see defining attributes as "the central and enduring attributes of an organization that distinguish it from other organizations" (Whetten, 2006: 220). The functional component of identity (distinctiveness) relies on the premise that, much like individual identity, organizational identity is relational and comparative (Ashforth and Mael, 1996; Whetten, 
2006). It is usually expressed by identity claims or labels that delineate to what the organization is similar and - explicitly or implicitly - to what it is not: "we are a school of information, not a school of culinary arts" (Gioia et al., 2013: 158); or "How could we exist as a company that was not in the memory business?" (Tripsas, 2009: 441). The structural component (central and enduring) refers to the fact that some features are so core to the organization that they are almost never questioned. Changing them is often unthinkable. Illustrating the notion of centrality, Whetten (2006: 226) states, "consider the implications of an organization switching from being a sporting goods retailer to a school," or of "3M rescinding its commitment to innovative products." Finally, the defining elements of an organization's identity must withstand the test of time. Although debate exists as to whether organizational identity can change, by now scholars agree that the features defining an organization's identity must exhibit some degree of continuity; if not enduring, they must be at least durable (Gioia et al., 2013; Whetten, 2006).

At the same time, organizational identity is not observable. Although its meaning is expressed with, communicated by, and tightly linked to labels (Gioia et al., 2013), identity claims (Ashforth and Mael, 1996), identity statements (Brickson, 2005), or identity references (Whetten, 2006), organizational identity does not exist outside of stakeholders' minds. It lies in the realm of social cognition, as a shared perception of what the organization "is." Thus, as a socially constructed, intersubjective property, organizational identity "cannot exist unless people agree that it exists" (Ashforth and Mael, 1996: 28). Finally, in line with Tripsas (2009), we see identity as how the organization is perceived by both organizational members and key audiences. This is not to say that all stakeholders view an organization in exactly the same way, but that there is a working consensus among insiders and key audiences regarding its identity. The greater the consensus, the more confidently we can speak of an organization's identity (Ashforth and Mael, 1996). We assume that such working consensus exists - that what insiders think the organization "is" is consistent with outsiders' perceptions. We address cases where organizational identity is ambiguous or where identity is yet to be formed separately in subsequent sections.

Organizational identity is consequential because it influences what organizational members pay attention to and how they process and interpret information (Dutton and Dukerich, 1991; Gioia et al., 2013). It also affects external stakeholder expectations, and thus organizations are positively rewarded when they engage in activities consistent with their identity (Tripsas, 2013; Zuckerman, 1999). More fundamentally, though, as identity filters environmental stimuli, it restricts the range of opportunities that managers attend to. Market opportunities consistent with the organization's identity are more likely to be identified by a firm (Tripsas, 2009); market opportunities inconsistent with a firm's identity are unlikely to lead to action, as "what does not get noticed, does not get considered" (Ashforth and Mael, 1996: 50). Thus, the likelihood that a firm will identify a market opportunity depends on identity correspondence, defined here as the degree of alignment between the firm's identity and the market opportunity (cf. Snow and McAdam, 2000). For example, otherwise similar companies attend to markedly different opportunities if they identify themselves as a multimedia company versus a telecommunications company (Sarason and van Rekom, 2007); the set of market opportunities that are fitting for a bank perceived as a commercial lender may differ from those fitting for a retail bank (Ashforth and Mael, 1996), and there is a high degree of correspondence between the identity of Patagonia (a clothing company) as an environmentally friendly organization and its decision to enter the organic food business. ${ }^{1}$

We thus theorize a positive influence of identity correspondence on market entry. Because the distinctiveness of organizations' identity is often viewed and expressed in a binary manner that reflects membership in or exclusion from a social category (e.g. "we are a credit union, not a bank"; Whetten, 2006: 223), the relationship between identity correspondence and opportunity identification will be steep: it will be very low when the organization's identity is antithetical or 


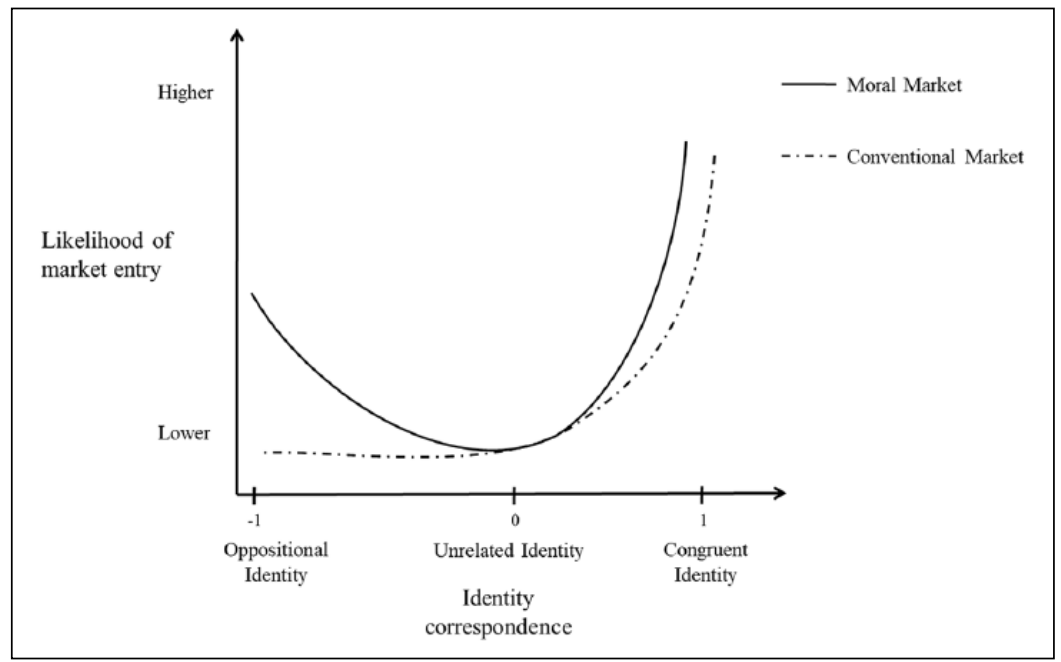

Figure 2. The impact of identity correspondence on moral market entry (Proposition I). The relationship between identity correspondence and market entry is increasingly monotonic for conventional markets (dashed line) but follows an asymmetric U-shaped pattern for moral markets (solid line).

simply irrelevant to the market opportunity, and it will be high when the organizations' identity is consistent with the market opportunity (i.e. when there is high identity correspondence). Yet, because organizational identity can vary in its clarity and because social categories such as market opportunities can be ambiguous, we expect that the shape of the relationship between identity correspondence and market entry is sharply increasing but not strictly binary.

To summarize, identity correspondence will have a positive effect on both opportunity identification and opportunity evaluation. In conventional markets, this relationship will be monotonically increasing. The likelihood of opportunity identification and evaluation will be low when identity correspondence is negative (oppositional identity) or when there is no correspondence (unrelated identity), and will sharply increase when identity correspondence is high (congruent identity) with the market. Since identification and favorable evaluation constitute two necessary conditions for market entry, we deduce that the relationship between organizational identity and market entry in conventional markets is as depicted in Figure 2.

Yet, the relationship between identity correspondence and market entry will be different in moral markets. Below, we present a theory of how organizational identity affects entry in moral markets.

\section{Social movements, organizational identity, and entry in moral markets}

Our theory is delimited to moral markets, sectors whose raison d'être is to offer market solutions to social and environmental issues. As discussed above, research has documented that social movements - defined as collectivities that engage in sustained action to contest, change, or resist change of prominent social, cultural, or business practices, and that are driven by shared beliefs, a collective identity, or both (Georgallis, 2017; Soule, 2009) — are a catalyst for moral market formation (e.g. Sine and Lee, 2009; Weber et al., 2008). Even if not a necessary condition, the involvement of social movements is a typical characteristic of moral markets and one that can change the dynamics of market entry choices. 
While work on social movements and market development has traditionally focused on the industry level of analysis (Durand and Georgallis, 2018), we can distill general mechanisms that underlie this relationship and that can explain the entry of economic agents into moral markets. First, social movements' efforts influence the propensity of economic agents to enter a moral market by shaping the range of opportunities they are likely to recognize; that is, they influence opportunity identification. Movements help delegitimize existing practices, which prompts the search for alternative market opportunities (Hiatt et al., 2009; Rao, 2008). They advocate solutions and provide information that shapes the attention of economic agents toward particular opportunities and increases their knowledge of how they can be exploited (Sine and Lee, 2009). They also tie market opportunities to widely held values and ideologies, altering the salience of those opportunities for managers who share those beliefs (Georgallis, 2017). These actions can increase the propensity of economic actors to enter a moral market.

Second, social movements contribute to the attractiveness, real or perceived, of market opportunities. That is, they influence opportunity evaluation. Activists confer sociopolitical and cognitive legitimacy upon markets, which facilitates resource acquisition by potential entrants and increases their survival chances (Aldrich and Fiol, 1994; Sine and Lee, 2009; York and Lenox, 2014). They strategically appeal to, and often prompt, "exogenous shifts in culture" (Eckhardt and Shane, 2003: 343), increasing demand for products that they favor, such as those that are greener, cleaner, or sweat-free. For instance, in a campaign to transform the US paper market, a coalition of non-governmental organizations (NGOs) mobilized to educate consumers about forestry and paper production practices. The coalition enlisted the corporate customers of Staples, the leading US retailer of office supplies, to its cause, which resulted in several universities' and more than 30 large companies' commitment to stop using old-growth wood and paper and aided the rise of a new segment for post-consumer recycled paper (O'Rourke, 2005).

Finally, social movements mobilize to enable the establishment of market infrastructure - such as networks of exchange between consumers and producers; a skilled labor force; knowledge of, and trust in, a technology; or favorable regulation (Lee et al., 2018) — which paves the way for economic agents to step in and take advantage of more attractive market opportunities (Lounsbury et al., 2003; Rao et al., 2000). By shaping the value of opportunities, social movements make market entry more likely.

These mechanisms matter in different ways for different firms. Firms do not pursue all opportunities that come to their attention, just as attractive market opportunities are not identified or perceived as relevant and value-enhancing by all firms (Ocasio, 1997; Penrose, 2009). Thus, the presence of a social movement in the development of a moral market creates important differences in firms' likelihood of entry into such a market, differences that arise from variation in organizational identity.

Organizational identity, with its attributes, often remain implicit for organizational members until some precipitating event makes the organization's identity more salient. The involvement of a social movement in a moral market can act as a trigger of "spontaneous cognitions" and bring organizational identity to the fore (Hsu and Elsbach, 2013). And while audience reactions are relevant for organizations in all markets, such reactions are often passive and retrospective. For instance, financial analysts discount firms that transcend the bounds of their identity (Zuckerman, 1999), but these are after-the-fact evaluations of strategic moves. By contrast, social movements actively participate in the construction of market opportunities and in shaping the range of actors that should or should not participate in moral markets. They form a key "legitimating audience" (Whetten, 2006) in the context of these markets.

Social movements, identity, and opportunity identification. Social movements tend to condone firms that have identities congruent with their aims and to condemn those with identities oppositional to 
their efforts. For instance, cultural codes such as sincerity, transparency, place, and personal relationships constructed by the movement that endorsed the market for grass-fed meat and dairy products garnered the attention of market participants when they were congruent with their identity (Weber et al., 2008). In such cases, identity functions as a guidepost, coordinating which issues will receive attention by decision-makers and screening out those that are irrelevant (Hoffman and Ocasio, 2001; Tripsas, 2009). Thus, firms tend to enter moral markets that are highly congruent with their identity, and the greater identity correspondence, the more likely it is that the firm will be aware of and identify the market opportunity.

By contrast, firms whose identities are oppositional to those expected by the movement may become the target of social movement groups. While some activist groups focus on the most reputable targets (Bartley and Child, 2011), others act as watchdogs that point to the most egregious offenders (Kölbel, 2016). Firms with oppositional identities can serve as mobilizing tools for such social movement organizations, as movements need to identify an enemy that will help them draw attention to the market and justify its reason for existence. For example, German activists successfully framed powerful, established pharmaceutical firms as salient enemies against which they formed an oppositional and insurgent identity (Weber et al., 2009). And proponents of the solar energy market framed incumbent energy companies as antagonists to promote the need for solar energy (Georgallis et al., 2018). Even if they are not the direct targets of activism, firms whose identity is challenged may also feel pressure to change certain practices to address movement concerns (Waldron et al., 2013; Yue et al., 2013). Thus, although firms often fail to notice opportunities that are oppositional to their identity (Tripsas, 2009), we posit that when a firm's identity is oppositional to the moral market, the firm is more likely to identify moral markets promoted by the movement. The argument is simple: while not necessarily willing to interpret opportunities promoted by activists as necessitating action (and for some firms the moral market may be seen as a threat), when firms' core identity is challenged directly or indirectly, they are more likely to be aware of the opportunities because such challenges elicit managerial attention.

Based on the above arguments, we expect a U-shaped pattern whereby, in moral markets, opportunity identification is more likely when a firm's identity exhibits either congruence with or opposition to the moral market. The lower likelihood of opportunity identification will be for firms that exhibit low or unrelated identity, or, in other words, for those organizations whose identity is irrelevant to the moral market. ${ }^{2}$

Social movements, identity, and opportunity evaluation. Identity not only serves as a filter that limits the recognition of issues but also guides interpretation and evaluation of external stimuli (Hoffman and Ocasio, 2001). Facing social movement influence and market opportunities that activists promote, firms contemplate questions such as "Who do we think we are? What do we think we should be?" These questions often guide their evaluations of market opportunities. If they identify strongly with the aims of a social movement, they will tend to evaluate movement claims in a positive light. At the same time, the more successful a movement has been at making opportunities more attractive, the more firms with identity correspondence will perceive them as "opportunities for them" (Haynie et al., 2009).

By contrast, organizations that possess oppositional identities will find it harder to pursue such endeavors. While they might be able to identify the opportunity, and even if the efforts of activists have created favorable market conditions, the degree to which it is attractive to them is diminished for two reasons. First, given the lack of correspondence between their identity and the expectations of the movement, the moral market may be seen by these companies as a threat rather than an opportunity, making alternative (other than market entry) responses appear more appropriate. Second, these firms may fear stakeholder reactions should they enter the market. For example, 
incumbent energy producers faced criticism after entering the solar energy market because their identity was viewed as oppositional to and incompatible with the very idea of green energy (Durand and Georgallis, 2018; Georgallis et al., 2018). Entering a market that is incongruent with conceptions of what the organization is or does challenges its identity and may result in negative evaluations by external audiences who tend to dismiss firms that act in "uncharacteristic, unrecognizable, inconsistent ways" (Whetten et al., 2009: 550). In fact, activists may themselves engage in "boundary control" (Gamson, 1997) to ensure that market participants adhere to their identity expectations or that firms do not "fake" their identities (further analyzed below). Overall, although opportunity identification suggests heightened possibility of market entry for firms with both oppositional and congruent identities, opportunities arising from movement efforts are likely to be seen as more attractive and less risky by actors with congruent identities. These firms face a similar or better "external" opportunity but lower risks of failure. Thus, in moral markets, social movements' efforts are more likely to lead to favorable evaluations of the market opportunity for firms with greater identity correspondence than for firms with an oppositional identity.

In sum, firms with identity correspondence and firms with oppositional identities are more likely to identify opportunities for moral market entry. Then, given opportunity identification, the former group of firms is more likely to evaluate the opportunity favorably. We can therefore deduce that the relationship between identity correspondence and entry in moral markets resembles an asymmetric U-curve. Figure 2 illustrates this relationship, where the right side of the curve corresponds to firms with a congruent identity and the left side corresponds to firms with an oppositional identity. At the same time, as Figure 2 shows, firms with an oppositional identity are - ceteris paribus - more likely to be led to market entry than firms with an unrelated identity (see the middle of the horizontal axis). The reason for this is twofold. First, as we have argued above, firms with unrelated identity are unlikely to identify these opportunities, and market entry is simply not possible if opportunity identification has not occurred. Second, even if firms with oppositional identities face possible social penalties from entry, the expected economic benefits that social movements create for these markets can sometimes exceed the perceived penalties of violating audience expectations, and thus their entry is hindered but not entirely precluded. Our prediction is formalized thus,

Proposition 1 (P1): In moral markets, the likelihood of market entry will be stronger for firms with greater identity correspondence than for firms with an oppositional identity; and stronger for firms with an oppositional identity compared than for with an unrelated identity.

The above arguments and a comparison of the two lines shown in Figure 2 suggest that the relationship between identity correspondence and market entry is markedly different in moral markets compared with conventional markets. Yet, this relationship may depend on both the organization at risk of entry and the social movement supporting the market. Below, we identify conditions that modify the shape of the theorized relationship: the flexibility of organizational identity and the type and framing-tactic orientation of the social movement. We then derive implications for entry by de novo versus de alio organizations.

\section{Organizational identity flexibility}

A general tenet of work on organization identity is that having well-defined "core" features is a necessary component of identity and that it is these core elements that make organizational members so resistant to change (Whetten, 2006). Furthermore, identity becomes deeply embedded in organizational routines, practices, and capabilities, which maintains the organization's current 
direction and delimits action to certain domains (Kogut and Zander, 1996). Meeting external expectations further reinforces identity claims because in meeting them, legitimacy is granted, ensuring ongoing operations and enhancing the probability of gaining needed resources.

Despite the importance of core features and their enduring nature to organizational identity, scholars have conceptualized and empirically identified instances of adaptive and purposeful identity change (Gioia et al., 2000) as well as instances of identity fluidity, instability, or ambiguity (Fox-Wolfgramm et al., 1998; Tripsas, 2009). Identity ambiguity often arises from discrepancies between the current and desired future identity (Corley and Gioia, 2004) or between internal and external identity (Tripsas, 2009); such discrepancies are more likely under conditions of extreme environmental change, of rapid structural change, or with startups (Corley and Gioia, 2004; Tripsas, 2009). Although sometimes seen as problematic, incongruities in identity can be an adaptive mechanism for organizational change. Identity ambiguity can make an organization more flexible because it creates opportunities to engage in strategies that depart from the organization's core elements - strategies that would otherwise be seen as unexpected or even inconceivable. In addition to ambiguity (lack of clarity) about the identity of the organization, identity flexibility can also be derived from the generality (lack of specificity) of the organization's identity. For instance, Polaroid's narrow identity as an "instant hardcopy company ... did not accommodate other digital imaging opportunities" (Tripsas, 2013: 27,32). Greater flexibility exists when identity is tied to a higher level of abstraction, since organizations with a broad organizational identity have more freedom to strategically enact their identity while maintaining a sense of continuity (Ashforth and Mael, 1996).

Organizations vary in how flexible their organizational identity is. In a study of the impact of regulatory change (the Community Re-Investment Act) on two Texas-based banks, Fox-Wolfgramm et al. (1998) found that the required changes could not be sustained in one bank because they were seen as inconsistent with its identity, but were permanently incorporated in the operations of a similar bank that had a more flexible identity. Using the concept of identity plasticity, the authors concluded that some organizations can change core features without necessarily altering their identity, but only if their identity is flexible enough to absorb these changes.

Because entry in moral markets requires varying degrees of deviation from an existing identity, the effect of identity correspondence on entry in such markets is likely conditional on the extent to which a given organization's identity is relatively fixed (concretely defined) versus flexible (abstract or ambiguous). Firms with a flexible identity can more easily present themselves as "appropriate" members of the moral market even if their identity is not as closely linked to what is expected of market participants. For instance, investment in renewable energy is likely seen as a more fitting market opportunity for an energy company than for a coal company. We thus expect the effect of organizational identity to be weaker for these firms than for firms with a relatively fixed identity, as flexibility expands the opportunities for organizations to depart from expectations and still satisfy stakeholders. Given some degree of identity flexibility, firms can make identity claims that will enable them to benefit from social movement support even if their identity is not fully congruent with the market (see the right side of the curve depicted in Figure 3).

The social penalties that firms face when deviating from expectations also depend on how their identity is perceived externally by key audiences (Pratt and Foreman, 2000). In Fox-Wolfgramm et al.'s (1998) study, prospector banks found it easier to satisfy stakeholders, as organizations with greater identity flexibility can engage in contradictory behavior while maintaining some degree of credibility. In the case of moral markets, social movement organizations and activists are key audiences for firms. When a firm with an identity inconsistent with a moral market considers entering that market, it can expect that identity flexibility will allow it to avoid, to some extent, stakeholder criticism. A firm is more likely to be scrutinized and penalized by activists if this move is clearly 


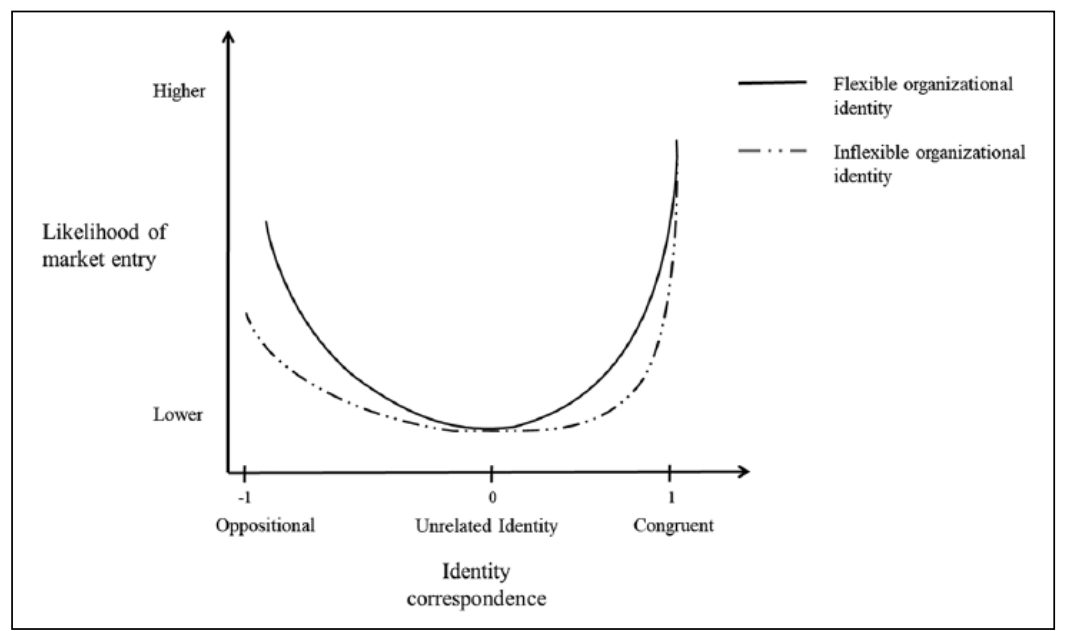

Figure 3. The impact of identity correspondence on moral market entry for firms with greater identity flexibility (Proposition 2).

Firms with a flexible organizational identity can receive benefits of entry even for lower identity correspondence; and can avoid scrutiny even if they have oppositional identities.

"identity-challenging" (Tripsas, 2013), that is, when its identity is unambiguously oppositional to what the moral market represents. When this is not the case, the firm can expect a lower level of opposition to its participation in the moral market, and hence market entry is more likely (see the left side of the curve depicted in Figure 3). Taken together, these arguments suggest that the baseline relationship described in P1 will vary depending on a firm's identity flexibility, as shown in Figure 3 and as formalized below:

Proposition 2 (P2): The impact of organizational identity on entry in moral markets will be less steep for firms having a congruent but more flexible organizational identity, and stronger for firms having an oppositional but more flexible organizational identity.

\section{Social movement type and framing-tactic orientation}

Beyond the organizational level, the effects of identity correspondence on market entry may be contingent on characteristics of the social movement supporting the moral market. Scholars have classified social movements into identity-oriented movements, which are driven by the need to express a common identity, and instrumental movements, which are driven by common external goals (Rao et al., 2003). Our discussion thus far has been general to both types of movements, but we believe that the nature of the movement will alter how identity correspondence shapes entry in moral markets (P1). While in practice social movements can fall anywhere between the two extremes, for clarity of exposition we discuss the two types of movements as ideal types.

Identity movements are driven more by the need to express an identity than to instigate broader societal changes (Rao et al., 2003). They tend to appear in markets that are more peripheral and distinctive, and that emphasize the authenticity of producers (Sikavica and Pozner, 2013). As such, identity correspondence likely plays a greater role in guiding entry decisions in markets supported by such movements than in those supported by instrumental movements. Given identity movements' emphasis on the authenticity of producers, identity-congruent firms will be-ceteris 
paribus - more likely to identify and favorably evaluate entry in a moral market when the market is backed by an identity movement.

In addition, firms with an oppositional identity likely perceive greater constraints when evaluating potential entry into identity markets. In these markets, authenticity and niche production are crucial, and the policing of the market's boundaries tends to be stricter. For instance, in the market for grass-fed beef, authenticity "found expression in valuing such practices as the family farm, personal interactions between producer and consumer, and the enjoyment of local food" (Weber et al., 2008: 539). By articulating practices that constituted authenticity for grass-fed-beef producers, activists simultaneously cast conventional growers who engaged in the practices of industrial farming, mass retail food, and highly processed food as inauthentic and therefore not legitimate players in the market. Thus, having a congruent identity is particularly important for markets backed by identity movements. Yet, as mentioned above, the presence of a supportive movement often means that the market becomes more attractive, as social movements stimulate demand and enable the development of market infrastructure. It is therefore possible that the expected costs of violating expectations are outweighed by the benefits of entering a more attractive market; thus we expect that - even for markets backed by identity movements - the interest of firms with an oppositional identity will be dampened but not necessarily eliminated. What is clear, however, is that because identity movements monitor market boundaries more vigorously, the benefits of identity correspondence will be higher in moral markets backed by such movements.

By contrast, producer authenticity is less a concern for a firm entering a moral market backed by an instrumental movement; activists supporting these markets tend to focus more on scaling markets and advocating products to the mainstream than on ensuring the authenticity of producers and their products. Thus, organizational identity is less important for them. For example, diversifying incumbents entering the green building sector (York and Lenox, 2014) are unlikely to face strong backlash from the environmental movement. The movement's primary goal is to ensure that green building practices diffuse widely rather than to verify the identity of market participants and their respective offerings. The above arguments and examples suggest that the effect of organizational identity will be stronger in moral markets supported by identity movements than in markets supported by instrumental movements. This is formalized below and graphically depicted in Figure 4:

Proposition 3 (P3): When an identity movement (rather than an instrumental movement) backs the moral market, the likelihood of market entry will be higher for firms with a congruent identity and lower for firms with an oppositional identity.

Another key feature of social movements that has been shown to influence a wide range of outcomes is framing. Movements' tactics can be broadly distinguished as supporting diagnostic framing - the identification of a problematic condition and the attribution of blame by identifying culpable agents; and prognostic framing - the prescription of a line of action for resolving the identified problem (Snow and Benford, 1992). Diagnostic and prognostic framing have been shown to be important for outcome attainment (Cress and Snow, 2000). While they often go hand in hand, there can still be substantial variation in movements' framing-tactic orientation, or the degree to which the social movement relies on prognostic versus diagnostic framing to promote its cause. We focus on this variation, arguing that the effect of organizational identity on moral market entry is contingent on the framing-tactic orientation of the social movement supporting the market.

The more a moral market is built on prognostic framing by the movement, the more likely it is that identity-congruent firms will enter the market. Prognostic framing includes the advocacy of 


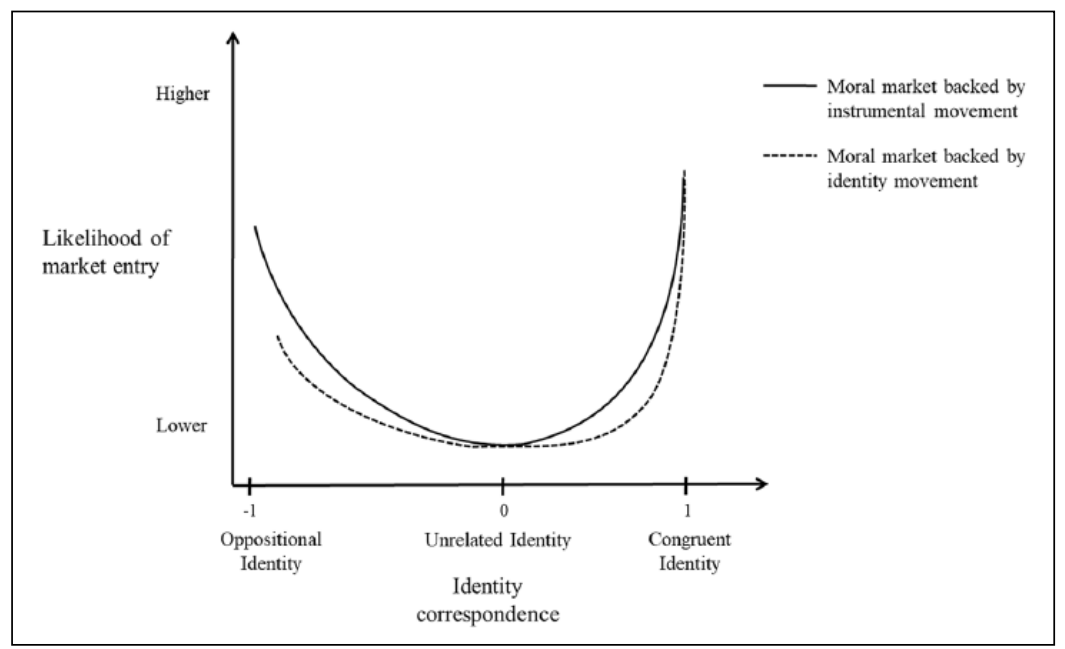

Figure 4. The impact of identity correspondence on moral market entry under different types of movements (Proposition 3).

In markets backed by identity (vs instrumental) movements, benefits accrue only to firms with highly congruent identities, and costs of entry are higher for firms with oppositional identities.

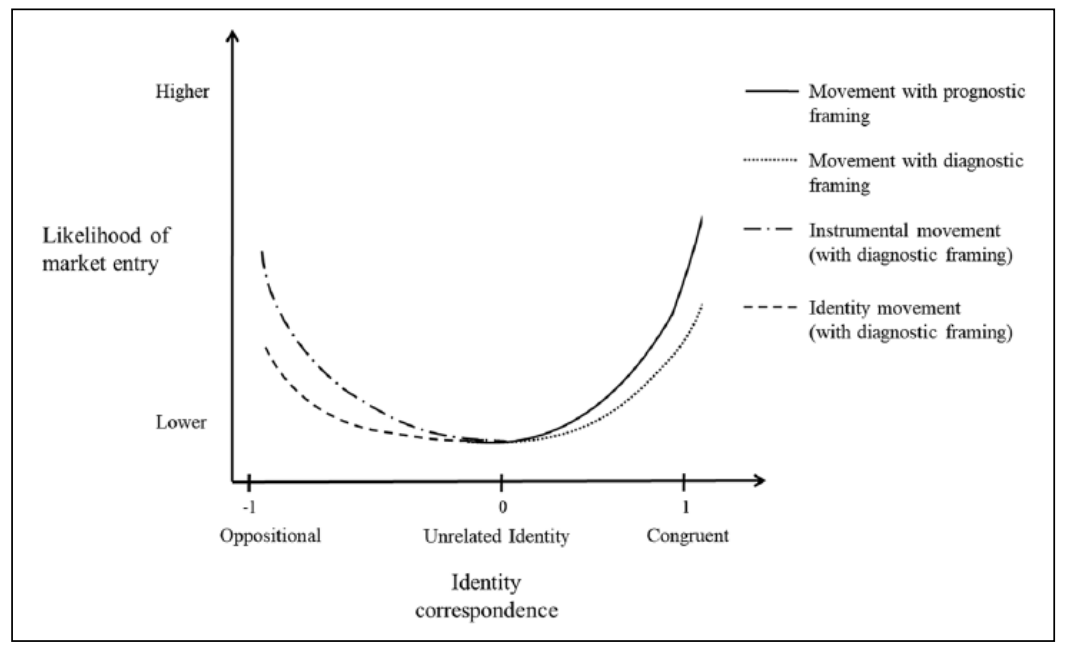

Figure 5. The impact of identity correspondence on moral market entry under different movement tactic orientations (Propositions 4, 5a and 5b).

Social movements relying more on prognostic framing increase the benefits of entry for identity-congruent firms (P4); Social movements relying more on diagnostic framing pose higher (vs lower) costs of entry for firms with oppositional identities if they are identity (vs instrumental) movements (P5a and P5b).

solutions that are consistent with a movement's goals, and at the same time grants legitimacy to producers and the market. The benefits of prognostic framing can include reputational gains for market participants, and those gains are more likely to accrue to firms whose identity is consistent with the moral market. For instance, in Europe, Greenpeace's campaigns to support the solar market included collecting signatures for the purchase of solar panels made by particular companies; 
however, the NGO chose to collaborate with and promote the products of "authentic" solar producers, firms whose identity fit well with the solar market (Durand and Georgallis, 2018). Generally, the organizations that activists use to grant empirical credibility to their prognostic framing are strategically chosen among exemplars, firms resembling "ideal-type" producers. Firms with unfit identities can rarely expect such benefits (Durand and Georgallis, 2018), which restricts these entry incentives to identity-congruent firms. That is, as a movement engages more deeply in prognostic framing, the right side of the solid U-curve depicted in Figure 5 will shift upward: a firm with a congruent identity will have stronger incentive for entry due to its perceived fit and higher expected benefits (see Figure 5). Formally, we suggest,

Proposition 4 (P4): The likelihood of market entry will be higher for identity-congruent firms when the moral market is backed by a movement focused primarily on prognostic, rather than diagnostic framing.

On the other hand, when the movement relies primarily on diagnostic framing, we expect a shift in the behavior of firms with an oppositional identity (the left side of the U-curve in Figure 5). Diagnostic framing is predicated on criticizing the incumbent system and pointing out flaws in established corporate practices. A firm with an oppositional identity is more likely to be targeted and thus to become aware of the opportunities for entry in the moral market. However, even though the chances of opportunity identification will rise, the likelihood of market entry will be further complicated depending on the type of movement.

Specifically, the perceived benefits are significantly lower when the firm faces an identity movement, because the company can expect, should it enter the moral market, to face substantial resistance by the movement. The movement is not only focusing on contention (diagnostic framing) but is also concerned about the market's authenticity and is therefore likely to react negatively to the entry of firms with inconsistent identity. By contrast, diagnostic framing will not reduce the benefits of entry when the movement is simply interested in expanding the market without reference to the nature of potential entrants (i.e. instrumental movements). In markets backed by instrumental movements that rely primarily on diagnostic framing, the firms having an oppositional identity will be more likely to identify the market opportunity but not less likely to evaluate it favorably. Formally,

Proposition 5 (P5): When the moral market is backed by a movement focused primarily on diagnostic (vs prognostic) framing, the likelihood of market entry will be (P5a) weaker for firms with oppositional identity if the market is backed by an identity movement; or (P5b) stronger for firms with oppositional identity if the market is backed by an instrumental movement.

\section{Implications for de novo and de alio entry}

To this point, we have delimited our discussion to entry by existing, diversifying firms (de alio), but our theory can be applied to entrepreneurial (de novo) entry into moral markets. Given that social movements have differential effects on firms having different identities, we suspect that the impact of social movements on de novo and de alio entrants will not be identical. On the face of it, it may appear awkward to consider how a theory of organizational identity applies to new firms. However, organizational identity is often an extension of founders' identities (Fauchart and Gruber, 2011), and these identities affect entrepreneurial action (Conger et al., 2018) by shaping "restrictive corridors" that filter and regulate how prospective entrepreneurs perceive opportunities (Fauchart and Gruber, 2011). Founders' identity may thus alter the influence of social movements on entrepreneurial entry in moral markets, just as organizational identity does for incumbent entry. We posit that the impact of social movements will be stronger for potential entrepreneurs whose 
identity fits with the moral market compared with de alio firms. In the US green building industry, sociocultural factors influenced de novo entry more than de alio entry (York and Lenox, 2014). We argue that the underlying cause of these differences can be traced to the fact that de novo and de alio entrants tend to differ in terms of their identity (Khessina and Carroll, 2008).

First, de novo entrepreneurial activity is more often driven by nonpecuniary considerations, including normative motivations and the need to express an identity (Fauchart and Gruber, 2011; York and Lenox, 2014). This is less often the case for de alio entry, as existing firms are more likely to be driven primarily by the need to achieve economic returns. Second, de novo and de alio firms differ in the extent to which their identity is flexible. Even when de novo firms' motivations are purely economic, any claims they make as being part of the solution to a social injustice are - given their status as newcomers - more credible than the claims of incumbent firms interested in entering the market (Hockerts and Wüstenhagen, 2010). Identity needs to be externally verified, and it is therefore more constraining for established organizations with whom audiences are already familiar. Once established, organizational identity is difficult to change; over time, organizations gain stability but lose flexibility with action being delimited to certain domains (Brickson, 2005). It is thus easier for young firms with an identity "in the making" to present themselves as congruent with emergent cultural logics in the environment than it is for an established firm to shift its identity, because a well-defined identity constrains future courses of action (Ravasi and Phillips, 2011; Tripsas, 2009). In sum, due to both the nature and the flexibility of their identity, we expect that de novo firms are more likely to be affected by social movements compared with de alio firms:

Proposition 6 (P6): The effect of social movements on the likelihood of entry into moral markets will be stronger for de novo firms than for de alio firms.

\section{Discussion}

In moral markets, social movements influence both the attractiveness of market opportunities and the attention of economic agents toward these opportunities. But while movements have a fieldlevel impact on moral markets, our theory suggests that organizational identity regulates the influence of social movements on firms' market entry decisions. The effects of organizational identity on moral market entry are complex and asymmetric, as identity induces firms with a congruent as well as firms with an oppositional identity to enter moral markets. Proposition 1 summarizes this central idea, and Figure 2 contrasts the role of organizational identity in moral markets with its role in conventional markets. Furthermore, we theorize that the relationship between organizational identity and market entry depends on identity flexibility, which allows firms to position themselves as congruent with the market even when they are not fully congruent, and to avoid criticism when market entry is identity challenging. Moreover, this relationship depends on the framing-tactic orientation of the social movement (the degree to which it relies on diagnostic or prognostic framing) and on the nature of the movement: whether an identity or an instrumental movement is backing the moral market. Finally, de novo (vs de alio) organizations are more likely to enter moral markets that social movements promote. Overall, by bringing together the literature on social movements with research on market entry and organizational identity, we highlight a fresh set of propositions that identify reasons why some firms enter moral markets while others do not.

\section{Contributions and implications}

Organizational identity and strategy. The idea that resource heterogeneity is at the heart of most strategic decisions has been a cornerstone of strategic management research (Barney, 1991; Penrose, 
2009; Peteraf, 1993). Scholars have developed models of market entry based on resources and capabilities, which form the stepping stones that firms can use to invest in adjacent markets. Clearly, strategy and resources are closely intertwined. At the same time, while it has long been recognized that strategy is reciprocally related to organizational identity as well (Ashforth and Mael, 1996), little attention has been paid to how identity affects market entry strategies.

If strategy is the answer to the question "where are we going?" and resources are "the means to get there," organizational identity addresses the question of "who we are" or "who they are" as an organization. As a shared perception of what the organization is, identity is purely cognitive and involves common understandings of the meaning of the entity (Ashforth and Mael, 1996; Brickson, 2005; Gioia et al., 2013). A focus on meanings and perceptions is important, as it surfaces two important points: that resources and organizational identity are related but not always tightly coupled, and that strategic decisions can sometimes be seen not as mere attempts for resource redeployment but as "expressions of the organization's distinctive character" (Whetten, 2006: 229). An account of the 1982 breakup of AT\&T illustrates how a sole focus on resources can sometimes be restrictive or even uninformative about organizations' strategic choices. Following an antitrust legal mandate, AT\&T was broken up into seven operating companies, each providing telephone services to a different region. These companies had shared history, culture, and similar resources; they were "as similar as any seven companies have ever been" (Sarason and van Rekom, 2007: 51). Yet, different beliefs about the identity of the organization (implied by statements such as "we are a multimedia company" or "we are a telecommunications company") eventually led each of these companies in markedly different strategic directions (Sarason and van Rekom, 2007). Thus, while resources and capabilities are critical for understanding market entry, a focus on organizational identity can add to the explanatory power of extant research in this area.

Consider as an illustration the solar photovoltaic industry, which has important resource complementarities with the semiconductor and electronics industries (Kapoor and Furr, 2015). Consistent with resource-centric explanations, companies like Sharp, Panasonic, and Canon had identified the solar photovoltaics market as a potential opportunity and entered the market early on (Marsh, 2009). More puzzling from the perspective of resource-driven entry, however, is the significant involvement of oil companies in this industry, since the oil industry relies on fundamentally different technology, culture, and routines (Ravi, 2011). Our theory can shed light on such dynamics, as we propose that social movements can be responsible for the entry not only of firms that are consistent with the market's identity but also of those that are clearly opposed. Furthermore, firms with oppositional identity can be seen as either "oil companies" or "energy companies," the latter label reflecting a more flexible identity, thus making entry in renewables more congruent with internal and external stakeholders' expectations.

Consistent with Whetten's (2006: 229) idea that organizational identity should be used conservatively, when "other explanations simply won't do," we suggest that a focus on social context and identity can help explain instances of entry that are not fully explained by resource- or capability-based theories. Instances of unrelated diversification may be particularly relevant for moral markets where social influences are salient, as context-dependent factors can sometimes substitute for internal resources in the process of identifying and evaluating opportunities (Kaplan, 2008; cf. Pacheco and Dean, 2015).

Social movements and markets. This study also contributes to research on the interaction between organizations, social movements, and markets. A number of studies have suggested that the presence of social movements not only limits the options permissible for organizations but also presents opportunities when market failures enable firms to (re)deploy their resources in new areas 
(Rao et al., 2000). Yet, scholars have increasingly called for a deeper examination of when firms respond to activism (Durand and Georgallis, 2018; Hiatt et al., 2015; Weber et al., 2009). Our theory suggests that organizational identity is a critical condition that alters the propensity of firms to enter the moral markets that social movements promulgate.

A focus on organizational identity enables us to identify the effects of social movements on the structure of moral markets. In contrast to institutional forces, usually seen as eliciting isomorphism, our theory suggests that social movements draw markedly different firms into moral markets, thus enhancing organizational diversity. This is important because organizational diversity affects both critical processes - such as coordination among market participants (Lee et al., 2018) - and outcomes - such as firms' subsequent growth (Durand and Georgallis, 2018), the establishment of collective identity (Lee et al., 2017), or the enactment of supportive policy (Georgallis et al., 2018). One implication revealed by our theory is that in allowing for a wider range of organizations to participate in the moral market, instrumental movements may inadvertently constrain market development, as greater organizational diversity has been argued to hamper collective action in some types of market formation efforts (Lee et al., 2017; McKendrick and Carroll, 2001; Ozcan and Santos, 2015).

\section{Boundary conditions}

To facilitate applications and extensions of our theory, we must delineate its boundaries. Our theory is developed for moral markets, so we do not expect our propositions to hold for conventional markets (shown in Quadrant IV of Figure 6). At the same time, we have focused on moral markets that are promoted by social movements (Quadrant I in Figure 6). The involvement of social movements is characteristic of moral markets, but there are exceptions. Markets that address societal problems are not necessarily promoted by social movements, and markets promoted by social

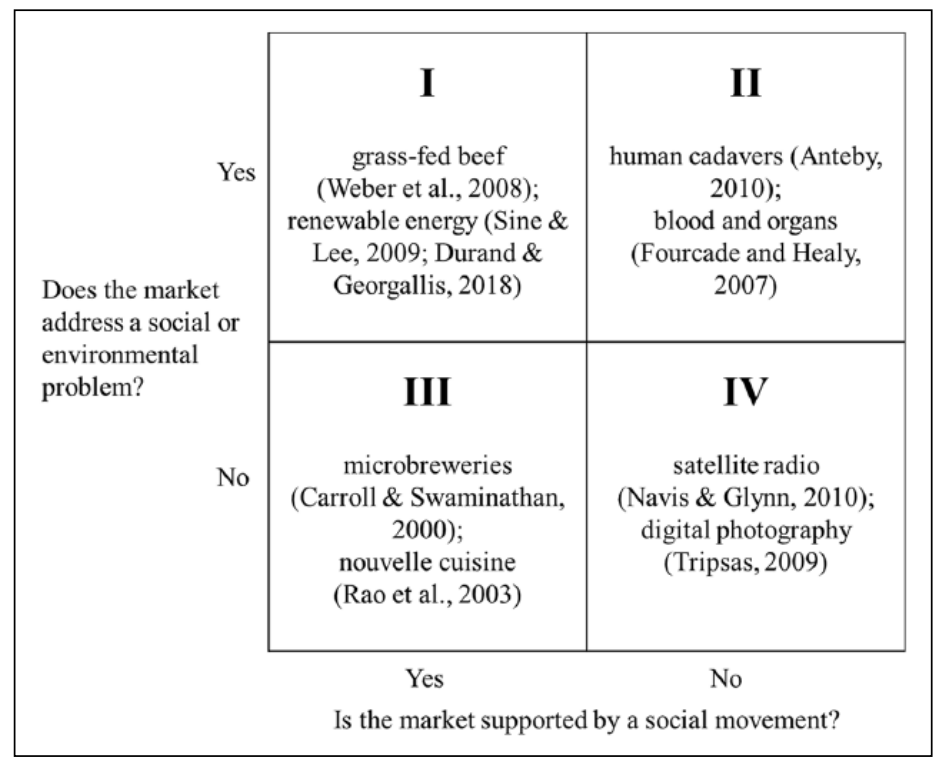

Figure 6. Boundary conditions of a theory of entry in moral markets. Relationship between moral markets and other markets, including examples. 
movements do not necessarily address societal problems (Weber et al., 2008). Would our theory translate to these other situations?

Consider first markets located in Quadrant II-moral markets whose products or services address societal problems but are not promoted by social movements. Such markets may exist for at least three reasons. First, social movements may have yet to identify the market as a solution to a social problem, which can happen for novel products in very early stages of commercialization. Second, social movements may simply not be present to promote these markets, which may be the case in poverty-stricken societies or under authoritarian regimes. Third, it is possible that some markets address social problems but their goods or services are perceived as belonging to the public or voluntary sphere and as unsuitable to for-profit market transactions. This may be true in the markets for blood, organs, or human cadavers, for example (Anteby, 2010; Fourcade and Healy, 2007). Our theory is unlikely to apply to these markets.

By contrast, we expect that our theory will hold for markets in Quadrant III, which concerns cases where a social movement is central to the successful emergence of a new market but where there is no strong social or environmental element. Examples of such markets are the microbreweries market (Carroll and Swaminathan, 2000) and nouvelle French cuisine (Rao et al., 2003). These markets were driven by producers' need to exhibit authenticity and a sense of collective identity rather than by the belief that the product or service helps create social value. Identity movements play an important role in the emergence of such markets, and organizational identity is generally a central concern. Thus, patterns of opportunity identification and evaluation will be similar to those in moral markets.

At the same time, it is in the markets supported by identity movements that the boundaries between firms and activists begin to dissolve. Identity movements often comprise the producers serving the market. Passionate entrepreneurs interested in expressing an identity occupy the roles of producer and activist simultaneously (Carroll and Swaminathan, 2000; Lee et al., 2017; Pozner et al., 2017). Blurring the boundaries between movement and firm appears to pose some challenges to our theory, as an implicit assumption was that the movement is external to the market. Yet, from the perspective of a particular firm or prospective entrepreneur, our propositions should still hold. Even if the activists are the producers, any given producer was at some point (i.e. prior to entry) not part of the producer-movement (with the exception of the very first entrants). The question then is what prompted the firm to participate in the moral market in the first place? Activists' efforts may well have contributed to this decision, especially if the firm's identity corresponds to the movement's expectations. This is, of course, a preliminary argument. Future research can extend these ideas to sketch out the full implications that producer-activist links pose for firms and markets.

\section{Future research directions}

One complication in testing and expanding on this study is the greater diversity in types of movements and organizations than what is depicted by our propositions. For clarity of theoretical exposition, we have presented sharp distinctions between identity and instrumental movements and between prognostic and diagnostic framing. We recognize, of course, that these ideal types are not found in reality and that each social movement shares elements of each. Nevertheless, our theory should capture differences in degrees that are both realistic and empirically observable. Similarly, we do not suggest that firms' identities are completely malleable or fully fixed; our theory can be applied to understand market entry by firms that differ in their degree of identity flexibility. Finally, entry in a moral market is often one of several possible opportunities that organizations face. Just as firms have different ways to enact their strategy, so too do they have different ways to enact their identity (Ashforth and Mael, 1996). Thus, our theory is not deterministic; our propositions should 
be seen as applying ceteris paribus (e.g. accounting for other opportunities that may be available to the firm). In other words, the likelihood of entry is increased under the conditions we theorize but is not fully determined.

The utility of the propositions developed here is contingent on their predictive efficacy. Understanding whether managers attend to the opportunities that activists proffer and how they evaluate them is a complex task. Given these difficulties, we expect our theory to be tested not in a single study but cumulatively. Assessment of attention based on experiments or secondary data (e.g. Kaplan, 2008; Laureiro-Martínez et al., 2015), large-scale panel data studies evaluating the link between activist campaigns and market development (Georgallis et al., 2018; Sine and Lee, 2009), or case studies of how organizational identity affects market entry (Tripsas, 2009, 2013) all offer opportunities for testing and expanding our theory. Moreover, examples that can guide the search for evidence of organizational identity exist, and include the use of surveys, case studies, and narrative analyses (see Foreman and Whetten, 2016; Ravasi and Canato, 2013, for a review of possible methodological strategies). Finally, simulation studies can be useful in assessing our arguments, as they are particularly appropriate to the study of complex and nonlinear relationships such as those we theorize (Davis et al., 2009).

An important consideration for future research is that our theory is not concerned with temporal dynamics, but such dynamics may alter some of the attributes we have theorized about. Recent empirical work on the US wind energy industry shows how social movements' impact on market entry evolves as markets develop. Early in this market's history, when it lacked legitimacy and adequate regulatory infrastructure and was unprofitable, the environmental movement was critical to its successful emergence (Sine and Lee, 2009; Vasi, 2010). However, as the market grew and attracted more entrants and state support, these developments attenuated the positive effect of social movements on market entry (Carlos et al., 2018). Relatedly, activists that instigated the market for technology assistance to nonprofits "went from being the future of nonprofit technology to almost complete obscurity" as the market grew and attracted more and more corporate interest (McInerney, 2014: 171). Similar patterns have been observed in another movement-driven market. Pozner et al. (2017) found that as the microbrewery market grew, some consumers were oblivious to the ideals of the identity movement that spawned it. This led to less detection and sanctioning of brewers' organizational identities and instead to a greater focus on the product itself. If moral markets backed by identity movements happen to scale and go mainstream (Lee et al., 2017), the degree to which organizational identity induces entry in moral markets is likely to be affected. Extensions to our framework can examine whether identity correspondence becomes less important as the close ties between a moral market and the movement supporting it weaken.

Organizational identity is central for our understanding of which opportunities actors identify, consider relevant, and eventually attempt to exploit (Denrell et al., 2003; Penrose, 2009; Tripsas, 2009). To maintain conceptual clarity, we have focused on organizations with a single identity, but some organizations possess multiple identities simultaneously. Like any strategic decision, evaluation of a market opportunity is more complex in organizations having multiple identities. A strong coherent identity can obviate organizational politics (Ashforth and Mael, 1996), but multiple identities can lead to conflict, disagreements, and internal politics that complicate strategic decisions. While we have not explicitly theorized about this, we see studies that elucidate the internal dynamics of entry decisions in multi-identity firms as a fruitful opportunity for future work. Future research should also attend to firm-level shifts in identity that may result from entering moral markets. Entry by firms with oppositional identity may lead to changing perceptions of the organization and eventually a more flexible identity, or to audience backlash and subsequent firm withdrawal from the market. Identifying under what conditions each of these outcomes is likely to occur is an important opportunity for future research. 
Beyond organizational identity, other factors critical for market entry may be important for entry in moral markets. While identifying all possible contingencies is beyond the scope of this article, one useful direction would be to examine whether firm resources affect entry into moral markets in ways that differ from how they affect entry in conventional markets. Another direction would be to study attributes that moderate the impact of activist campaigns on firm behavior, such as corporate reputation, or prior investments (Durand and Georgallis, 2018; King, 2008; King and Soule, 2007).

For market entry research, our framework opens up several additional questions worthy of future inquiry. For instance, our theory holds promise for research that examines not only whether but also when and how firms enter a market (e.g. Helfat and Lieberman, 2002). Research has paid much attention to the advantages and disadvantages of early entry but relatively less attention to the sources of entry timing (Zachary et al., 2015). Could variation in activism and organizational identity account for differences in when firms enter a moral market? Understanding this question would enrich environmental approaches to entry timing (Suarez and Lanzolla, 2007). And because identity conflicts are less acute when firms establish separate divisions to pursue a new technology (Tripsas, 2013), there may be a relationship between activist actions, identity, and mode of entry. We believe that such questions merit theoretical and empirical scrutiny.

\section{Conclusion}

Market entry is one of the most important and frequently studied topics in the fields of strategy and entrepreneurship, but the question of how social forces shape opportunities for entry and who is positioned to exploit them have not been central to the discussion. This article draws attention to social movements - forces responsible for some of the most fundamental societal changes of the past two centuries (Hiatt et al., 2009) — and organizational identity - a defining and deeply consequential firm feature - as sources of market formation and redefinition (Rao, 2008). Extending the links between organization theory, strategy, and entrepreneurship, this perspective highlights the importance of viewing economic activity as socially embedded, and demonstrates the relevance of evaluating contextual and organizational attributes in tandem. The tentative nature of scientific research implies that our theory will need to be tested, modified, and extended in order to mature. But we hope this research will stimulate further studies of how organizational identity affects market entry, and lay the groundwork for a more systematic and theoretically informed analysis of moral markets.

\section{Acknowledgements}

The authors would like to thank Flore Bridoux, Glen Dowell, Rodolphe Durand, Susan Kayser, Brayden King, Jocelyn Leitzinger, Costas Markides, Bertrand Quelin, Todd Schifeling, Tatiana Sokolova, and participants at the GRONEN reading group session at ESADE Business School for their insightful comments and feedback on earlier drafts. An earlier and abridged version of this article appeared in the Academy of Management 2015 Best Paper Proceedings and received the Best Conceptual Paper Award from the Academy's Entrepreneurship Division.

\section{Declaration of Conflicting Interests}

The author(s) declared no potential conflicts of interest with respect to the research, authorship, and/or publication of this article.

\section{Funding}

The author(s) disclosed receipt of the following financial support for the research, authorship, and/ or publication of this article: This research draws from the first author's doctoral dissertation, which was financially 
supported by the Strategy Research Foundation, the Society and Organizations ( $\mathrm{SnO}$ ) Research Center at HEC Paris, and the HEC Paris Leadership Center. Georgallis' research is supported by NWO VENI grant 016-125-283.

\section{Notes}

1. On its website, Patagonia explains that its rationale for entering this market is that

[we] believe there is great opportunity - and an urgent need - for positive change in the food industry. With Patagonia Provisions, our goals are the same as with everything we do: We aim to make the best product, cause no unnecessary harm, and perhaps most important, inspire solutions to the environmental crisis. (https://www.patagoniaprovisions.com/pages/why-food-essay)

2. This does not imply that firms with unrelated identity will never enter a moral market (they might still identify such opportunities for other reasons: serendipity, explorative search, peer competitive intelligence, etc.), but that they will not identify these opportunities on account of their identity.

\section{ORCID iD}

Panayiotis (Panikos) Georgallis (iD) https://orcid.org/0000-0001-9898-5220

\section{References}

Albert S and Whetten DA (1985) Organizational identity. Research in Organizational Behavior 7: 263-295.

Aldrich HE and Fiol CM (1994) Fools rush in? The institutional context of industry creation. Academy of Management Review 19: 645-670.

Anteby M (2010) Markets, morals, and practices of trade: Jurisdictional disputes in the U.S. commerce in cadavers. Administrative Science Quarterly 55: 606-638.

Arjaliès DL (2010) A social movement perspective on finance: How socially responsible investment mattered. Journal of Business Ethics 92: 57-78.

Ashforth BE and Mael FA (1996) Organizational identity and strategy as a context for the individual. Advances in Strategic Management 13: 19-64.

Barney J (1991) Firm resources and sustained competitive advantage. Journal of Management 17: 99-120.

Bartley T and Child C (2011) Movements, markets and fields: The effects of anti-sweatshop campaigns on U.S. firms, 1993-2000. Social Forces 90: 425-451.

Brickson SL (2005) Organizational identity orientation: Forging a link between organizational identity and organizations' relations with stakeholders. Administrative Science Quarterly 50: 576-609.

Carlos, WC, Sine, WD, Lee B, et al. (2018) Gone with the wind: The evolving influence of social movements and counter movements on entrepreneurial activity in the US wind industry. In: Dorobantu S, Aguilera RV, Luo J, et al. (eds) Sustainability, Stakeholder Governance, and Corporate Social Responsibility (Advances in Strategic Management) (vol. 38) Emerald Publishing Limited, pp. 339-364.

Carroll GR and Swaminathan A (2000) Why the microbrewery movement? Organizational dynamics of resource partitioning in the U.S. brewing industry. American Journal of Sociology 106: 715-762.

Conger M, McMullen JS, Bergman BJ, et al. (2018) Category membership, identity control, and the reevaluation of prosocial opportunities. Journal of Business Venturing 33: 179-206.

Corbett J and Montgomery AW (2017) Environmental entrepreneurship and interorganizational arrangements: A model of social-benefit market creation. Strategic Entrepreneurship Journal 11: 422-440.

Corley KG and Gioia DA (2004) Identity ambiguity and change in the wake of a corporate spin-off. Administrative Science Quarterly 49: 173-208.

Cress DM and Snow DA (2000) The outcomes of homeless mobilization: The influence of organization, disruption, political mediation, and framing. American Journal of Sociology 105: 1063-1104.

Davis JP, Eisenhardt KM and Bingham CB (2009) Optimal structure, market dynamism, and the strategy of simple rules. Administrative Science Quarterly 54: 413-452. 
Denrell J, Fang C and Winter SG (2003) The economics of strategic opportunity. Strategic Management Journal 24: 977-990.

Durand R and Georgallis P (2018) Differential firm commitment to industries supported by social movement organizations. Organization Science 29: 154-171.

Dutton JE and Dukerich JM (1991) Keeping an eye on the mirror: Image and identity in organizational adaptation. Academy of Management Journal 34: 517-554.

Eckhardt JT and Shane SA (2003) Opportunities and entrepreneurship. Journal of Management 29: 333-349.

Fauchart E and Gruber M (2011) Darwinians, communitarians, and missionaries: The role of founder identity in entrepreneurship. Academy of Management Journal 54: 935-957.

Foreman PO and Whetten DA (2016) Measuring organizational identity: Taking stock and looking forward. In: Pratt MG, Schultz M, Ashforth BE, et al. (eds) The Oxford Handbook of Organizational Identity. New York: Oxford University Press, pp. 39-64.

Fourcade M and Healy K (2007) Moral views of market society. Annual Review of Sociology 33: 285-311.

Fox-Wolfgramm SJ, Boal KB and Hunt JG (1998) Organizational adaptation to institutional change: A comparative study of first-order change in prospector and defender banks. Administrative Science Quarterly 43: 87-126.

Gamson J (1997) Messages of exclusion: Gender, movements, and symbolic boundaries. Gender \& Society 11: $178-199$.

Georgallis P (2017) The link between social movements and corporate social initiatives: Toward a multi-level theory. Journal of Business Ethics 142: 735-751.

Georgallis P, Dowell G and Durand R (2018) Shine on me: Industry coherence and policy support for emerging industries. Administrative Science Quarterly 64: 503-541.

Gioia DA, Patvardhan SD, Hamilton AL, et al. (2013) Organizational identity formation and change. The Academy of Management Annals 7: 123-193.

Gioia DA, Schultz M and Corley KG (2000) Organizational identity, image, and adaptive instability. Academy of Management Review 25: 63-81.

Haynie JM, Shepherd DA and McMullen JS (2009) An opportunity for me? The role of resources in opportunity evaluation decisions. Journal of Management Studies 46: 337-361.

Helfat CE and Lieberman MB (2002) The birth of capabilities: Market entry and the importance of prehistory. Industrial and Corporate Change 11: 725-760.

Hiatt SR, Grandy JB and Lee BH (2015) Organizational responses to public and private politics: An analysis of climate change activists and U.S. oil and gas firms. Organization Science 26: 1769-1786.

Hiatt SR, Sine WD and Tolbert PS (2009) From Pabst to Pepsi: The deinstitutionalization of social practices and the creation of entrepreneurial opportunities. Administrative Science Quarterly 54: 635-667.

Hockerts K and Wüstenhagen R (2010) Greening Goliaths versus emerging Davids-Theorizing about the role of incumbents and new entrants in sustainable entrepreneurship. Journal of Business Venturing 25: 481-492.

Hoffman AJ and Ocasio W (2001) Not all events are attended equally: Toward a middle-range theory of industry attention to external events. Organization Science 12: 414-434.

Hsu G and Elsbach KD (2013) Explaining variation in organizational identity categorization. Organization Science 24: 996-1013.

Jaffee D and Howard PH (2010) Corporate cooptation of organic and fair trade standards. Agriculture and Human Values 27: 387-399.

Kaplan S (2008) Cognition, capabilities, and incentives: Assessing firm response to the fiber-optic revolution. Academy of Management Journal 51: 672-695.

Kapoor R and Furr NR (2015) Complementarities and competition: Unpacking the drivers of entrants' technology choices in the solar photovoltaic industry. Strategic Management Journal 36: 416-436.

Kennedy MT (2008) Getting counted: Markets, media, and reality. American Sociological Review 73: 270295.

Khessina OM and Carroll GR (2008) Product demography of de novo and de alio firms in the optical disk drive industry, 1983-1999. Organization Science 19: 25-38. 
King BG (2008) A political mediation model of corporate response to social movement activism. Administrative Science Quarterly 53: 395-421.

King BG and Soule SA (2007) Social movements as extra-institutional entrepreneurs: The effect of protests on stock price returns. Administrative Science Quarterly 52: 413-442.

Kogut B and Zander U (1996) What firms do? Coordination, identity, and learning. Organization Science 7: $502-518$.

Kölbel J (2016) Sustainability and risk: The role of stakeholders. PHD Dissertation, ETH Zurich, Zurich. Available at: https://doi.org/10.3929/ethz-a-010610140

Laureiro-Martínez D, Brusoni S, Canessa N, et al. (2015) Understanding the exploration-exploitation dilemma: An fMRI study of attention control and decision-making performance. Strategic Management Journal 36: 319-338.

Lee B, Hiatt S and Lounsbury M (2017) Market mediators and the trade-offs of legitimacy-seeking behaviors in a nascent category. Organization Science 28: 447-470.

Lee B, Struben J and Bingham C (2018) Collective action and market formation: An integrative framework. Strategic Management Journal 39: 242-266.

Lounsbury M, Ventresca M and Hirsch PM (2003) Social movements, field frames and industry emergence: A cultural-political perspective on US recycling. Socio-Economic Review 1: 71-104.

McInerney PB (2014) From Social Movement to Moral Market: How the Circuit Riders Sparked an IT Revolution and Created a Technology Market. Stanford, CA: Stanford University Press.

McKendrick DG and Carroll GR (2001) On the genesis of organizational forms: Evidence from the market for disk arrays. Organization Science 12: 661-682.

McMullen JS and Shepherd DA (2006) Entrepreneurial action and the role of uncertainty in the theory of the entrepreneur. Academy of Management Review 31: 132-152.

Marsh G (2009) PV manufacture: Synergy without dependence. Renewable Energy Focus 10: 48-53.

Mitchell W (1989) Whether and when? Probability and timing of incumbents' entry into emerging industrial subfields. Administrative Science Quarterly 34: 208-230.

Moeen M (2017) Entry into nascent industries: Disentangling a firm's capability portfolio at the time of investment versus market entry. Strategic Management Journal 38: 1986-2004.

Nag R, Corley KG and Gioia DA (2007) The intersection of organizational identity, knowledge, and practice: Attempting strategic change via knowledge grafting. Academy of Management Journal 50: 821-847.

Navis C and Glynn MA (2010) How new market categories emerge: Temporal dynamics of legitimacy, identity, and entrepreneurship in satellite radio, 1990-2005. Administrative Science Quarterly 55: 439-471.

Ocasio W (1997) Towards an attention-based view of the firm. Strategic Management Journal 18: 187-206.

O'Rourke D (2005) Market movements: Nongovernmental organization strategies to influence global production and consumption. Journal of Industrial Ecology 9: 115-128.

Ozcan P and Santos FM (2015) The market that never was: Turf wars and failed alliances in mobile payments. Strategic Management Journal 35: 1486-1512.

Pacheco DF and Dean TJ (2015) Firm responses to social movement pressures: A competitive dynamics perspective. Strategic Management Journal 36: 1093-1104.

Pacheco DF, York JG and Hargrave TG (2014) The coevolution of industries, social movements, and institutions: Wind power in the United States. Organization Science 25: 1609-1632.

Penrose E (2009) The Theory of the Growth of the Firm. Oxford: Oxford University Press.

Peteraf MA (1993) The cornerstones of competitive advantage: A resource-based view. Strategic Management Journal 14: 179-191.

Pozner J-E, DeSoucey M and Sikavica K (2017) Bottle revolution: Constructing consumer and producer identities in the craft beer industry. IRLE working paper, University of California, Berkeley, Berkeley, CA, March.

Pratt MG and Foreman PO (2000) The beauty of and barriers to organizational theories of identity. Academy of Management Review 25: 141-143.

Rao H (2008) Market Rebels: How Activists Make or Break Radical Innovations. Princeton, NJ: Princeton University Press. 
Rao H, Monin P and Durand R (2003) Institutional change in Toque Ville: Nouvelle cuisine as an identity movement in French gastronomy. American Journal of Sociology 108: 795-843.

Rao H, Morrill C and Zald MN (2000) Power plays: How social movements and collective action create new organizational forms. Research in Organizational Behavior 22: 237-281.

Ravasi D and Canato A (2013) How do I know who you think you are? A review of research methods on organizational identity. International Journal of Management Reviews 15: 185-204.

Ravasi D and Phillips N (2011) Strategies of alignment: Organizational identity management and strategic change at Bang \& Olufsen. Strategic Organization 9: 103-135.

Ravi KV (2011) Déjà vu all over again. Future Photovoltaics, August. Available at: http://www.xtalsolar .com/news/FPV5_N_WP_Ravi_FVCC.pdf

Sarason Y and van Rekom J (2007) Organizational identity and formulating strategy. In: Lerpold L, Ravasi D, van Rekom J, et al. (eds) Organizational Identity in Practice. New York: Routledge, pp. 50-62.

Shane S (2012) Reflections on the 2010 AMR decade award: Delivering on the promise of entrepreneurship as a field of research. Academy of Management Review 37: 10-20.

Sikavica K and Pozner JE (2013) Paradise sold: Resource partitioning and the organic movement in the US farming industry. Organization Studies 34: 623-651.

Sine WD and Lee BH (2009) Tilting at windmills? The environmental movement and the emergence of the U.S. wind energy sector. Administrative Science Quarterly 54: 123-155.

Snow D and Benford R (1992) Master frames and cycles of protest. In: Morris AD and McClurg Mueller C (eds) Frontiers in Social Movement Theory. New Haven, CT: Yale University Press, pp. 133-155.

Snow D and McAdam D (2000) Identity work processes in the context of social movements: Clarifying the identity/movement nexus. In: Stryker S, Owens TJ and White RW (eds) Social Movements, Protest, and Contention: Volume 13. Self, Identity, and Social Movements. Minneapolis, MN: University of Minnesota Press, pp. 41-67.

Soule SA (2009) Contention and Corporate Social Responsibility. Cambridge: Cambridge University Press.

Suarez FF and Lanzolla G (2007) The role of environmental dynamics in building a first mover advantage theory. Academy of Management Review 32: 377-392.

Tolbert PS, David RJ and Sine WD (2011) Studying choice and change: The intersection of institutional theory and entrepreneurship research. Organization Science 22: 1332-1344.

Tripsas M (2009) Technology, identity, and inertia through the lens of "The Digital Photography Company." Organization Science 20: 441-460.

Tripsas M (2013) Exploring the interaction between organizational identity and organizational design in technological transitions. Working paper, Boston College, Chestnut Hill, MA, August.

Tripsas M and Gavetti G (2000) Capabilities, cognition, and inertia: Evidence from digital imaging. Strategic Management Journal 21: 1147-1161.

Vasi IB (2010) Winds of Change: The Environmental Movement and the Global Development of the Wind Energy Industry. Oxford: Oxford University Press.

Waldron T, Navis C and Fisher G (2013) Explaining differences in firms' responses to activism. Academy of Management Review 38: 397-417.

Weber K, Heinze K and DeSoucey M (2008) Forage for thought: Mobilizing codes in the movement for grass-fed meat and dairy products. Administrative Science Quarterly 53: 529-567.

Weber K, Rao H and Thomas L (2009) From streets to suites: How the anti- biotech movement affected German pharmaceutical firms. American Sociological Review 74: 106-127.

Whetten D (2006) Albert and Whetten revisited: Strengthening the concept of organizational identity. Journal of Management Inquiry 15: 219-234.

Whetten D, Felin T and King B (2009) The practice of theory borrowing in organizational studies: Current issues and future directions. Journal of Management 35: 537-563.

York J, Vedula S and Lenox M (2018) It's not easy building green: The impact of public policy, private actors, and regional logics on voluntary standards adoption. Academy of Management Journal 61(4): $1492-1523$.

York JG and Lenox MJ (2014) Exploring the sociocultural determinants of de novo versus de alio entry in emerging industries. Strategic Management Journal 35: 1930-1951. 
Yue LQ, Rao H and Ingram P (2013) Information spillovers from protests against corporations: A tale of Walmart and Target. Administrative Science Quarterly 58: 669-701.

Zachary MA, Gianiodis PT, Payne GT, et al. (2015) Entry timing: Enduring lessons and future directions. Journal of Management 41: 1388-1415.

Zietsma C and Lawrence TB (2010) Institutional work in the transformation of an organizational field: The interplay of boundary work and practice work. Administrative Science Quarterly 55: 189-221.

Zuckerman EW (1999) The categorical imperative: Securities analysts and the illegitimacy discount. American Journal of Sociology 104: 1398-1438.

\section{Author biographies}

Panayiotis (Panikos) Georgallis is an assistant professor of Strategy at the Amsterdam Business School, University of Amsterdam (UvA). He holds a PhD in Strategic Management from HEC Paris. Panikos' research focuses on interactions between firms, social movements, and governments, particularly as they relate to the dynamics of sustainable industries. His work in this area has been published in leading journals such as Administrative Science Quarterly, Organization Science, Journal of Business Ethics, and Long Range Planning, and has been recognized with several distinctions. His doctoral dissertation was awarded the Strategy Research Foundation Dissertation Scholars Grant and was a finalist for the Academy of Management ONE Division Best Dissertation Award. Recently, Panikos was awarded a Veni grant from the Netherlands Organization for Scientific Research (NWO) to study the emergence and evolution of moral markets.

Brandon Lee is an associate professor of strategy at Melbourne Business School. His research interests include the role of collective action in market formation, environmental sustainability, the regulation of new markets, and certification processes in industries. He has recently published work in this area in Organization Science, Strategic Management Journal, and Advances in Strategic Management. He is currently conducting research on carbon markets, the transformation of the disability sector in Australia and unmanned aerial vehicles. He serves on the editorial boards of Administrative Science Quarterly and Academy of Management Journal and received his $\mathrm{PhD}$ in organizational behavior from the School of Industrial and Labor Relations at Cornell University. 


\section{University Library}

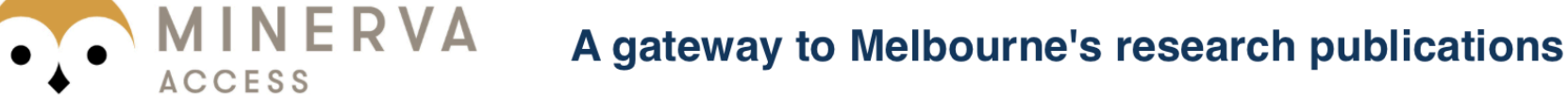

Minerva Access is the Institutional Repository of The University of Melbourne

Author/s:

Georgallis, P;Lee, B

Title:

Toward a theory of entry in moral markets: The role of social movements and organizational identity

Date:

2020-02-01

Citation:

Georgallis, P. \& Lee, B. (2020). Toward a theory of entry in moral markets: The role of social movements and organizational identity. Strategic Organization, 18 (1), pp.50-74. https:// doi.org/10.1177/1476127019827474.

Persistent Link:

http://hdl.handle.net/11343/252278

License:

cc-by-nc 